[McGeorge, C. (2000). Private Schools in New Zealand: An Endangered Species? New Zealand Annual Review of Education, 9, 83-96]

\section{Private Schools in New Zealand: An Endangered Species?}

\section{COLIN MCGEORGE}

\section{Abstract:}

The number of private schools has declined over the last decade, prompting the Chief Review Officer to express concern, but the non-government school sector as a whole has grown with many private schools, including recently established ones, integrating into the state system. The size of the non-government sector and movement within it will depend on the level of state aid and the new government's willingness to act on recent amendments to the Integration Act.

$\mathrm{O}$ ver the last decade in New Zealand education there appears to be far less private initiative at the compulsory school level than at the pre- and post-compulsory levels, as measured by the relative numbers of educational institutions. Numbers of private preschool and tertiary facilities have increased markedly, while the number of private schools has declined from 136 in 1990 to 105 in January 2000.

The Chief Review Officer expressed concern in 1998 over the decline in the numbers attending private schools. Enrolments had fallen from 3.8 percent of all school enrolments in 1991 to 3.5 percent in 1997. She observed that the state might soon have a virtual monopoly, with a "potential loss of ownership as an indicator of comparative performance." How, in that case, could performance in the education sector be compared with diversified service sectors like health? (Education Review Office, 1998, pp. 3-5).

The fall in the number of private schools is partly attributable to closures and mergers but most of it is due to what the Chief Review Officer refers to as "the generous incentives offered by the state for entry to the public domain" (Education Review Office, 1998, p. 3), primarily contained in the Integration Act 1975. Under that Act, a

\section{Colin McGeorge}

private school may elect to become part of the state system with the right to maintain its "special character" while receiving the same operational and salary funding as other state schools. There were 251 integrated schools in 1990; at the beginning of 2000 there were 325, so that the total number of "non-government" (private plus integrated) schools has actually increased by $43(105-136+325-251)$ over this period. Where did the extra schools come from, and what are they?

New Zealand Gazette notices of the integration of private schools and the Ministry of Education's annual directories of New Zealand schools were used to construct the database on which Table 1 is based. It shows that the private sector has been much more volatile than summary statistics suggest, with more than two hundred private schools registered at one time or another over the last ten years. ${ }^{1}$

Table 1 New Zealand Private Schools 1990 - 2000

\begin{tabular}{lccc}
\hline & \multicolumn{3}{c}{ Registered Private Schools } \\
\cline { 2 - 4 } Status in & Open & Opened & All \\
2000 & in 1990 & $1991-2000$ & schools \\
\hline State & 2 & 11 & 13 \\
Private & 63 & 42 & 105 \\
Integrated & 61 & 9 & 70 \\
Closed & 10 & 13 & 23 \\
Total & 136 & 75 & 211 \\
\hline
\end{tabular}

The private schools which became state schools were newly established kura kaupapa Maori. Section 155 of the Education Act 1989 provides for kura kaupapa Maori to be established as state schools, but some kura get under way first as private schools. Most of the private schools which have closed since 1990 were Christian schools, and most of them were very small. Twelve of the closed schools had fewer than 20 pupils in their last year of operation.

Even when the developing kura are deducted, the private school sector has been more active than it might first appear. Forty-two of the current private schools did not exist in 1990; and seventy private schools have integrated since then. Since 1990, another seven schools have opened as integrated schools without going through the more customary stage of registration as a private school. These seven include 
four Catholic schools, the first entirely new Catholic schools for many years.

Table 2, which is based on a list of private and integrated schools, supplied by the Ministry of Education on request, gives the numbers of private and integrated schools clearly affiliated with a particular denomination or educational approach, plus schools whose name includes the word "Christian". The relatively large group of "other" schools includes a number which describe themselves as undenominational. Some of these schools, although they do not use the word in their names, might have been classified as "Christian" schools while others are, in effect, Anglican or Presbyterian schools but do not formally identify themselves as such. "Other" private schools with no religious associations include the preparatory schools operated by Nelson College and Nelson College for Girls, the recently established Junior and Senior Colleges in Auckland, and Tamariki School in Christchurch.

Table 2 Non-government schools 1999

\begin{tabular}{lrc}
\hline & Private & Integrated \\
\hline Abundant Life & 21 & 1 \\
Anglican & 2 & 12 \\
Assembly of God & 2 & 1 \\
Baptist & & 237 \\
Catholic & 1 & 1 \\
Hare Krishna & 1 & 1 \\
Jewish & & 1 \\
Latter Day Saints & 1 & 1 \\
Methodist & 2 & 4 \\
Muslim & 7 & 7 \\
New Life & & 1 \\
Presbyterian & & 17 \\
Reformed Church & 28 & 17 \\
Seventh Day Adventist & 3 & 7 \\
"Christian” & 3 & 1 \\
Steiner & 39 & 319 \\
Montessori & 110 & \\
Other & & \\
Total & & \\
\hline
\end{tabular}

By 1983, all the Catholic schools and a handful of Protestant schools had integrated, leaving only 101 private schools. On the assumption that the major denominations were unlikely to establish new schools, one might have predicted that the number of private schools would remain at about that level, but in fact the number of private schools increased in the 1980s. A significant proportion of the new private schools identified themselves as "Christian" and used imported curriculum materials, most commonly the highly structured Accelerated Christian Education (ACE) booklets originating in Texas. In 1986, 20 out of 113 private schools were using ACE (Education Statistics of New Zealand, 1987, p. 21) although inspectors of schools had strong reservations about its suitability in New Zealand (Department of Education, 1984, Part 2, p. 64). Other Christian curriculum packages are now on offer, but in 1998, the principal of a Christian academy claimed that 29 New Zealand schools still used the ACE programme, now known as "School of Tomorrow" (Worboys, 1998).

In the early 1980s, private schools received significant state aid, including 50 per cent of the cost of staffing according to state scales, but the fourth Labour Government announced that salary subsidies would be phased out by 1990. In 1990, the private schools were still receiving the aid they had received in the 1960s before the salaries grant was introduced, but this was small change, and they protested that they were paying more in GST than they received in state aid.

The withdrawal of salary subsidies brought a sharp increase in applications to integrate. Five non-Catholic private schools applied to integrate between 1976 and 1988, but 33 applied between 1988 and 1991 (Integration Review Committee, 1991, p. 2).

When in Opposition, the National Party promised to restore 50 percent salary subsidies if elected, but it did not set a timetable. Once elected, the new National Party government provided 20 per cent subsidies, but in 1993 the Minister of Education said that, "In the current fiscal climate no further rise could be contemplated" (The Press, 1993, p. 8). In reply to those who opposed even this partial restoration, the Minister argued that it would, in fact, save public money because it would ease the pressure on private schools to integrate with the state system.

The 20 percent subsidy clearly did not have the desired effect; schools continued to integrate, and the government could be charged with inconsistency when it approved the integration of small private 
schools while planning the closure of small rural schools to obtain economies of scale.

In the 1980s, integrating schools could obtain cheap or suspensory loans for buildings. In the 1990s, these loans were restricted to schools which had integrated before 1992, but this did not stop schools applying to integrate. The principal effect of withdrawing government loans appeared to be an increase in the attendance dues integrated schools could charge to service debts incurred through building programmes. Annual attendance dues in Catholic schools in 1994 ranged from \$101 to $\$ 120$ for primary school pupils and from $\$ 240$ to $\$ 297$ for secondary pupils, depending on the diocese (O'Neill, Corrigan \& Lynch 1994, p. 3), while the dues at a Presbyterian school which had just integrated were $\$ 1,700$ (NZ Gazette, 1994, p. 2415). Attendance dues at recently integrated schools are also substantial: $\$ 1750$ plus GST per annum at Lindisfarne (NZ Gazette, 1999, p. 124) and \$1470.50 including GST at Westminster Christian School (New Zealand Gazette, 1999, p. 562).

Notwithstanding the Minister's comments in 1993, state aid increased significantly in the later 1990s under a National government. It was announced in 1995 that private schools would receive a single grant to replace salary subsidies and other items of state aid. The new grant would be in proportion to per pupil costs in an equivalent state school. Private school pupils in Years 1 - 10 would be funded at 25 per cent of state school costs per pupil, rising to 30 per cent in 1999, and Year 11-13 pupils at 40 per cent.

Changes in policy since 1985 are clearly reflected in the total grant to private schools for running costs. In 1984-85, these grants amounted to $\$ 13.18$ million; by $1990-91$, with the withdrawal of salary subsidies, they had fallen to $\$ 5.29$ million; and in 1998-99, under the new system pegged to state school costs, they amounted to $\$ 41.32$ million (AJHR, B.7, Part 1, 1985, p. 46; B.7, Part 1 1991, p. 263; B.5, vol. 1, 1999, p. 606).

Per capita grants to private schools increased by 176 per cent between 1984-5 and 1998-9 while the Consumers' Price Index rose by 117 per cent, but although state aid was higher in real terms than it had been before the salary subsidy was withdrawn, applications to integrate continued.

In 1991, an integration review committee noted that private schools which applied were more or less guaranteed integration; and the committee suggested amending the Integration Act 1975 to empower the Minister to decline an application. This recommendation, however, was not taken up until 1998 when the Act was amended to require private schools to apply to the Minister to enter into negotiations for integration. The Minister, when considering such an application, must "consider the nature, character and capacity of the existing network of schools" (Private Schools Conditional Integration Amendment Act 1998, section 3) and may take other factors into account. A disappointed applicant is free to apply again at any time, but:

The Minister has an absolute discretion to accept applications to enter into negotiations under this Act and may from time to time,

after giving such public notice as he or she considers appropriate, decide not to consider applications from particular areas.

(Private Schools Conditional Integration Amendment Act 1998, section 3 )

The amending act has, however, also removed an obstacle to the establishment or expansion of an integrated school. Until 1998, the proprietors had to own the school site or hold the land upon trust, but they may now lease it (Private Schools Conditional Integration Amendment Act 1998, section 13).

Both these new provisions were invoked early in 2000. The Minister declined an application to establish a new integrated girls' school near Wellington, and a Catholic school opened in premises leased from the Crown and formerly occupied by a state primary school (EDUVAC, 2000,. p. 3)

Under the new legislation, and under a Labour-Alliance government, one would expect more applications to integrate and some of these to be declined. Labour has promised to "cap funding levels for private schools at the existing per pupil and total funding levels" (New Zealand Labour Party, 1999, p. 15), while "The Alliance supports the existence of private schools but notes that, where good public alternatives exist, there is no justification for state funding of the private sector" (Gordon, 1999).

The Labour and Alliance election manifestos both promised an end to the Targeted Individual Entitlement (TIE) scheme announced in 1995, and in February 2000 the new Minister of Education announced that no new TIE places would be awarded in 2001 so that the scheme will end when the existing awards run out. (TIE places may be held for up to six years.)

Under the Targeted Individual Entitlement scheme, a caregiver could apply for a place in a private school if the combined household annual taxable income was less than $\$ 25,000$ ("Asset rich families should 
not apply") and no other child in the family/household was enrolled in a TIE place (Ministry of Education, 1998a).

The TIE scheme provided up to 160 places a year, 80 in primary and 80 in secondary schools. The subsidy on TIE pupils is topped up to 110 per cent of the cost of a place in an equivalent state school and "The Independent School usually makes up any difference between this payment and the usual school fee" (Ministry of Education 1998a). A supplementary allowance is paid to families to assist with uniform, travel and other costs. This allowance, $\$ 900$ for a primary pupil and $\$ 1100$ for a secondary pupil, is paid for three years in any case, and is thereafter subject to the limit on household income.

The TIE scheme was introduced for a three year trial period with an independent assessment. In 1998, the Minister of Education said he had received two interim reports on TIE and the second of them indicated that the scheme had reached its targeting objective in 1997: "It has supported single parents from an ethnically diverse mix of families. More than two-thirds of students selected by schools to participate in the 1997 TIE scheme came from sole parent families" (New Zealand Parliamentary Debates, vol. 573, 1998, pp. 1357-8). There was no plan, the Minister said, to lift the cap on numbers and a decision on continuing the scheme would be made after considering the evaluators' final report, due in 1999.

The final report, dated July 1999, concluded that the scheme was "successful in facilitating access to private schooling for a small group of students from low income New Zealand families" (Gaffney \& Smith, 1999, executive summary). As TIE places for 1999 had already been allocated, the report appeared simply to confirm a decision already taken to continue the scheme indefinitely.

What, in addition to Christian charity or social duty, might have prompted the better-known private schools to subsidise a judicious number of TIE places? The Independent Schools Council favours "entitlements" (it shuns the term "vouchers"), and argues:

Every student should receive a basic entitlement. It should not vary according to the school the student attends. A fairer deal for parents is for their entitlement to the Government's education dollar to follow the child to the school they choose. That is what genuine choice in a democracy is all about. (Independent Schools Council, 2000)

The capped, means-tested TIE scheme fell well short of the automatic, portable entitlement the Independent Schools Council hankered for, but it provided a useful precedent. If it could be shown that TIE pupils were socially and ethnically diverse and performed well, private schools could argue that this showed how all sorts and conditions of person might benefit from private schooling if restrictions on "entitlements" were lifted.

The Independent Schools Council currently advises visitors to its Web site that tuition fees in its member schools range from $\$ 2,000$ to $\$ 6,600$ per annum for primary schools and from $\$ 3,700$ to $\$ 8,700$ for secondary schools, plus GST; and boarding fees are from $\$ 4,800$ to $\$ 6,500$. The closer to the top of the range its fees are, the more a TIE place costs a private school.

TIE pupils would, however, benefit private schools whose per-pupil costs were less than 110 per cent of state costs, and this may account for the number of places some schools offered to provide. In 1997, in reply to a question in the House, the Minister of Education gave the number of places private schools had offered to provide and the number they were allocated. The three highest bidders were Christian Heritage College which bid for 22 places and was allocated 2, Westminster Christian School (bid for 20, got 6) and Wanganui Collegiate (bid for 15, got 10). Of the eight schools not allocated any places, one was a Steiner school and five were Christian schools. One of the unsuccessful Christian schools had fewer than 20 pupils and offered to provide 6 TIE places; another, which had fewer than 10 pupils, offered to provide two places (New Zealand Parliamentary Debates: Questions for Written Answer, vol. 26, 1996-1997, pp. 214-5).

Although they may include appeals to the UN Declaration of Human Rights or be expressed in Treasury-speak, recent arguments for state aid are essentially the same as those advanced a century ago. Some arguments, however, are less common these days, or are expressed by different groups. Before the Integration Act, which guarantees the "special character" of these schools, Catholics argued that denying them state aid limited their freedom of religion because they were taxed twice, once to provide state schools which were unacceptable to them and once to support Catholic schools. Private schools these days are more likely to present double taxation as a simple injustice rather than a penalty on religious belief. Recent appeals to religious freedom have come from small "Christian" schools rather than the major denominations, and religious freedom has usually been invoked to defend the way the school operates rather than to lobby for increased state aid. When, for example, corporal punishment was abolished in 
1990, some Christians said that this limited their freedom to follow God's will in dealing with children.

A major argument against state aid in the nineteenth century was that it would imperil the national school system. Catholics were the most persistent claimants to state aid, but one could hardly grant them aid and deny it to others, and then what was to stop other denominations' schools springing up everywhere? The funds which should go to support an effective single system would be frittered away in the churches' uncoordinated efforts.

By the 1960s, the denominational antagonisms, suspicions and pretensions which dogged nineteenth century debate had virtually disappeared. This rapprochement not only ensured the easy passage of the Integration Act, it also meant that the Act did not have the dire consequences which those opposed to state aid predicted. Parsons had other fish to fry in the 1970s and there was no sudden growth in the numbers of Anglican, Presbyterian or Methodist schools. There are many more church schools now than there were in 1975, but most of them are associated with smaller evangelical groups and their aggregate enrolments do not constitute a threat to the state system.

The Integration Act means that non-government schools get state aid under two sets of terms and conditions with more strings attached to the higher level of funding. An integrated school must have a board of trustees and a charter, it is funded and staffed to state scales and must meet the same accounting requirements, and it is obliged to teach the national curriculum. Additional legal requirements were also imposed on private schools in the 1990s - for example, their teachers must now be registered or hold a "limited authority to teach" and they may no longer administer corporal punishment, but a private school still has far more freedom of action than either a state or an integrated school.

The percentage of pupils in non-government schools has increased over the last twenty-five years, but not dramatically. In 1975, 11.1 percent of pupils were in private schools (Department of Statistics, 1976, p. 975); the equivalent figure in March 1999 was 13.4 per cent, comprising 10.0 per cent integrated and 3.4 per cent private (Ministry of Education, 1999, p. 6)

These figures suggest that the percentage in non-government schools will only rise slowly (if at all), with more movement within the non-government sector than into or out of it. So far, the movement has all been from private to integrated, but the Integration Act provides for the cancellation of an integration agreement and for the disposal of property in that event. No integrated school has opted back out of the state system so far, but an integrated school might consider this step if state aid to private schools increased significantly under some future administration, or if state requirements could not be reconciled with the school's special character.

Integrated schools are obliged to teach the national curriculum, and problems can arise when a school's programme is shaped rather than flavoured by its special character. A recent guide to New Zealand secondary schools cites ERO reports which highlight this difficulty in two integrated Steiner schools. A 1997 report on one of these schools says, "The way in which the Waldorf curriculum and national curriculum can be linked to meet requirements as a state integrated school must continue to be explored" (Lilly, 1998, p. 160). A 1998 report on the other school describes the students as creative, confident, articulate, safe and happy and "not yet, however, receiving the national curriculum, and they are entitled to do so" (Lilly, 1998, p. 62). The problem arises because Steiner prescribed what and how children should be taught and he died in 1925 without having foreseen, on the basis of his work in "occult science," what the New Zealand curriculum would be like in the 1990s. The same problem arises when "Christian" schools opt for imported curriculum materials.

The number of private schools in the early years of this century will depend on the level of state aid and the way in which the amended Integration Act is administered. Increased aid after 1995 did not stop schools applying to integrate, and it may be politically difficult for the Minister to make full use of his new power to decline an application to negotiate. Unsuccessful applicants can still argue that to deny their children a particular sort of schooling denies freedom of religion; and were the Minister to decline an application because what was proposed would compromise the delivery of the national curriculum, the applicants might point to existing integrated schools and demand consistency of treatment.

It has been suggested that there is no longer any need for the "secular clause" which prohibits religious teaching in state primary schools and that it might be dropped when the Education Act 1964, which is still in force and includes the secular clause, is consolidated with an updated Education Act 1989 (New Zealand Parliamentary Debates: Questions for Written Answer, vol. 23, 1996, p. 5377). The deletion of the secular clause would probably not lead to a rush to offer religious 
instruction in state primary schools, but it would provide an argument for increased state aid. Integrated primary schools could argue that with the disappearance of this essential difference between them and other state primary schools, the requirement that they provide their own land and buildings is no longer justified; and private schools' case for portable "entitlements" would be strengthened.

Private schools have always been a varied group, and some of their critics and supporters have talked at cross-purposes with different sorts of school in mind. For many, if not most, people, "private school" means a long-established Anglican or Presbyterian secondary school, and this is how private schools usually appear in the media; but there are more "Christian" than Anglican or Presbyterian private schools, and 40 per cent of New Zealand's private schools were established less than ten years ago. The Independent Schools Council has 36 North Island members and 10 in the South Island, including two Christian schools, the recently established Senior and Junior Colleges in Auckland, and the older-established Anglican and Presbyterian schools. Of the 41 schools offering new TIE places in 1999, 36 were affiliated with the Independent Schools Council. When the Independent Schools Council speaks for its members, it speaks for less than half of the private schools - there is no single voice for the other schools.

Private schools, over all, have a lower pupil: teacher ratio than state schools, and private school pupils are more likely than state school pupils to stay at school beyond age sixteen and more likely to leave school with Form 7 qualifications (Ministry of Education, 1998b, p. 13). These simple statistics do not, as some assume, put the superiority of private schools beyond doubt. It would be surprising if some private schools did not have good examination statistics in view of their clientele and resources. But research by Hughes, Strathdee \& Lauder (1996) also suggests that private school pupils do not do as well at university as one would predict on the basis of their school examination marks, while state school pupils do better than expected.

In 1996, the Chief Review Officer told a private school conference that her agency classified 7 percent of private schools as "excellent/ exemplary." These were all long-established, single-sex schools with substantial private support in addition to their income from fees and state aid. The bulk of private schools were competent but "A small proportion are not competent as service providers - and almost all of these are small schools, usually self-defined as "Christian" and delivering a specialist and brand-named curriculum" (Aitken, 1996).
Presumably, the Chief Review Officer is more worried about the disappearance of some private schools than others - state schools do not require an external standard with which to compare their eurhythmy lessons or their success in persuading children that present land forms are all due to Noah's flood.

Private schools are not a single endangered species, but they do include some remarkable survivors, some rare breeds and some recent hybrids. The size of this group of schools is largely determined by the level of aid and the terms on which schools can integrate; the range of school types owes more to overseas developments. Many Christian schools, particularly in their early years, were faithful copies of American schools; other schools have been modelled on Neill's "Summerhill", and there is renewed interest in Montessori methods, which had a vogue early in the twentieth century (Miltich-Conway \& Openshaw, 1988). Some overseas models are not represented amongst New Zealand private schools, For instance, no school has taken up the Scharz-Metterklume method, and the only military academy is an adjunct to a state secondary school and limited to senior pupils. The most likely additions to the range of private schools in New Zealand seem to be schools established by immigrant ethnic or religious minorities, but one should never underestimate some middle-class New Zealanders' enthusiasm for overseas models or the eye of others for a promising commercial opportunity.

Note

1. Strictly speaking, more than 250 private schools have been registered over that period, i.e., assigned a separate school number in a Ministry register, but more than 40 of them were artefacts of the registration system rather than separate institutions. A number of private schools began as primary schools which later developed secondary departments. Initially, these secondary departments were registered as separate schools, and in due course, the school was given a new, third number when it was registered as a composite school. In a few cases, a composite school has reverted to a primary school and been given yet another registration number. Institutions which have been registered as two or more separate"schools" over the years are only counted once in Table 1.

\section{References}

Aitken, J. (1996). Private schools - alternative schools. Paper presented to Independent Schools Conference, Auckland. 
Appendix to the Journal of the House of Representatives (AJHR). (1861-). Wellington: Government Printer.

Barrington, J. (1996). School privatisation: A review and critique. New Zealand Annual Review of Education, 5, 43-56.

Department of Education. (1984). Briefing papers provided to the Hon. Russell Marshall, Minister of Education. Wellington: Department of Education.

Department of Education. (1964-1989). Education statistics of New Zealand. Wellington: Department of Education.

Department of Statistics. (1976). New Zealand official yearbook 1976. Wellington: Government Printer.

Education Review Office. (1998). Report of the Education Review Office for the year ended 30 June 1998. Wellington: Education Review Office. (AJHR, E.39, 1998.)

Gaffney, M. \& Smith, A. (1999). Evaluation of the TIE scheme: Report to the Ministry of Education. Dunedin: Children's Issues Centre, University of Otago.

Gordon, L. (1999). Zoning, no bulkfunding and reduced funds for private schools. Media statement, 26 August 1999. Web site <http://www.alliance.org.nz>

Hughes, D., Strathdee, R. \& Lauder, H. (1996). First-year university performance as a function of type of secondary school attended and gender. New Zealand Journal of Educational Studies, 31(1), 13-28.

Independent Schools Council. (2000). Web site

$<$ http://www.independent.school.nz>

Integration Review Committee. (1991). The review of integration policy. Wellington: Ministry of Education.

Lee, G., \& Lee, H. (1998). The state aid and integration debate in New Zealand education, 1877-1988: Policies, problems and possibilities. Waikato Journal of Education, 4, 149-173.

Lilly, C. (1998). A guide to 300 + New Zealand secondary schools. Auckland: Hodder Moa Beckett.

McGeorge, C. (1995). Private and integrated schools in New Zealand: Subsidising the illusion of choice. Journal of Educational Policy 10(3), 259-270.

Miltich-Conway, B. \& Openshaw, R. (1988). The Montessori method in the Wanganui Education Board District 1911-1924. New Zealand Journal of Educational Studies, 23(2), 189-202.

Ministry of Education. (1990- ). Education Statistics of New Zealand. Wellington: Ministry of Education.
Ministry of Education. (1998a). Targeted Individual Entitlement Scheme (TIE)/application for acceptance for participation in Targeted Individual Entitlement (TIE) Scheme. Wellington: Ministry of Education.

Ministry of Education. (1998b) March school statistics report 1998. Wellington: Data Management and Analysis Division, Ministry of Education.

Ministry of Education. (1999) March school statistics report 1999 Wellington: Data Management and Analysis Division, Ministry of Education.

Ministry of Education. (2000). Directory of New Zealand schools and tertiary institutions. Wellington: Data Management and Analysis Division, Ministry of Education.

New Catholic school starts with healthy roll. (2000). EDUVAC: The Education Weekly, 11(406), p. 3.

New Zealand Gazette (NZG) (1861 -). Wellington: Government Printer.

New Zealand Labour Party. (1999). Labour on schools. Wellington: New Zealand Labour Party. Web site < http://www.labour.org.nz>

New Zealand Parliamentary Debates: Questions for Written Answer. (NZPD/QWA). (1995-). Wellington: Government Printer.

New Zealand Parliamentary Debates. (1861-). Wellington: Government Printer.

O'Neill, J., Corrigan, P. \& Lynch, P. (1994). New Zealand Catholic schools strategic planning guide: Scoping document. Wellington: National Council of Proprietors of Catholic Integrated Schools.

Private school subsidy increases. (1993, February 10 ). The Press

Worboys, D. (1998, October 15 ). Letter to editor. The Dominion.

\section{The author}

Colin McGeorge is a senior lecturer in the Education Department of the University of Canterbury. He has published papers on the social and moral content of nineteenth and early twentieth century schooling. He is currently working on a history of schemes to reform and reorganise the New Zealand school system. 